\title{
The Washback Effect of School-Based Oral Evaluation Performance and Its Causal Relationship with Fear of Negative Evaluation
}

\author{
Mohd Nazri Latiff Azmi and Rosnah Mohd Sham \\ Faculty of Languages and Communication, Universiti Sultan Zainal Abidin \\ Gong Badak Campus, 21300 Kuala Nerus, Terengganu, Malaysia \\ Email: rosnahmohdsham@gmail.com
}

\begin{abstract}
This paper presents part of a study that investigates the washback effect of a School-Based Oral Evaluation (SBOE) performance from the teachers' perceptions. It also investigates the causal relationship between students who have passed in the school-based oral evaluation (SBOE) with fear of negative evaluation. The participants are 302 of form four students and four English teachers from the Putrajaya Federal Territory government secondary schools in Malaysia. It is a mixedmethod study in which the data were collected in sequential, analysed separately, and then explained. The quantitative data were collected by using FLCAS, the School-Based Oral Evaluation (SBOE) results and the qualitative data were collected from the semi-structured interviews with the English teachers and guidelines on SBOE from the Ministry of Education Malaysia. The quantitative method used descriptive statistical analysis, whereas the qualitative method used content analysis. Students' result in the mid-term examination 2017 shown that they had scored high marks in the SBOE. The quantitative results revealed that the students had experienced low mean level of fear of negative evaluation. The teachers reported that students had shown positive attitude during the SBOE and English class interaction. They were focused, confident, responsive and not panic. There is a positive washback effect of SBOE on the students' result. High results in SBOE affected the mean level of fear of negative evaluation. The partial etasquared showed the value of 0.106 which is considered high. This study suggests two broad future tasks. The first task involves the development of national curriculum in English language which is dependent upon oral English language. The second task focuses on the development of English language training and skills for the English teachers.
\end{abstract}

Keywords: washback effect, School-Based Oral Evaluation performance, causal relationship, negative evaluation 


\section{Introduction}

The School-Based oral evaluation performance is the form four students' School-Based Oral Evaluation (SBOE) result. SBOE is the oral language for the government secondary school students. It is conducted twice a year, from April to June and from July to September (Malaysia, Ministry of Education 2017). It tests the students' proficiency in speaking the English language, listening comprehension skill, and testing the students' ability to comprehend speech in daily situations (Malaysia, Ministry of Education 2017). The concepts are to observe and to monitor, and the objective is to avoid irregularities. The SBOE is implemented according to the schedule and procedure. The modus operandi is to monitor each pupil individually. The schools are monitored at least once a term by the officers from the State Education Department. SBOE comprises $30 \%$ of the English subject Paper 1119. It also includes handling assessment of the school candidates, models, bands and criteria for assessment. The Examination Syndicates, Ministry of Education Malaysia, has set a manual contains the framework and guidelines for the implementation of SBOE. In order to provide candidates with essential information in preparing for the test, these frameworks and guidelines are designed to assist teachers to conduct the test. The Examination Syndicates has developed four models for the implementation of the SBOE. Candidates have to prepare their own materials for assessment purposes according to the examples illustrating in each model. The SBOE performance in this paper is the SBOE result in the mid-term English examination 2017. The question papers for the mid-term examination are set by the Examination Syndicates, Ministry of Education Malaysia. The English subject for form four students is included in the Malaysian Certificate of Education which is known as Sijil Pelajaran Malaysia (SPM). The English language subject for form four and form five students in secondary schools in Malaysia is called Paper 1119 Bahasa Inggeris. It is divided into oral and written languages.

This study investigates 302 form four students and four English teachers from the secondary schools that have produced the highest number of students passed in English subject in SPM for the last 10 years (Malaysia, Ministry of Education 2017) in Malaysia. The purpose of this study is to investigate the effectiveness of the SBOE by determining the washback effect of SBOE performance and its causal relationship with fear of negative evaluation. It will provide a base for future research for the Ministry of Education Malaysia in the implementation of a new English oral-based curriculum. So far, only a few studies have been done in Malaysian schools up to this point. Based on the researcher's critical investigation of the literatures at the time of this study, there are still gaps to investigate the washback effect of the school-based oral performance and its causal relationship with fear of negative evaluation.

The term 'washback' in language research can be traced at the beginning in the early 1990s. A classic article with the title 'Does Washback Exist?' by Alderson and Wall (1993) was published as a seminar paper. The paper has greatly influenced all major recent research reports and literature reviews in the area of washback in language 
testing. The writers were the first to look critically at the notion of test 'washback' and the way in which washback had been treated as a 'unique hypothesis'. They discovered a 'poor' test would have negative washback while a 'good' test would have positive influence.

Fear of negative evaluation is the apprehension about others' evaluations and avoidance of evaluative situations (Horwitz, Horwitz and Cope, 1986, p. 127). It is one of the components in Language Anxiety (Horwitz, Horwitz and Cope, 1986). The students feared of failing in the classroom, feared of forgetting vocabularies and unprepared of teachers' questions (Shabani, 2012). Theory has proved that fear of negative evaluation is one of the components in language anxiety has found to be the main factor which is affecting language learning and the most powerful predictor on the students' target language performance (Liu and Huang, 2011). The affective filter hypothesis of Krashen's classic theory (1982) has proved that language anxiety acts as an effective filter and impedes language learning. Inputs are prevented from reaching the language acquisition device (LAD) in the brain to those who are not proficient in the target language (Krashen, 1982). Therefore, it is assumed that students who experience fear of negative evaluation could not speak well in the English language even to those who have scored well in the English subject. Fear of negative evaluation and language performance are negatively related to each other. However, previous studies revealed inconsistency results and findings. There is no a clear-cut relationship between English performance and fear of negative evaluation as a component in language anxiety. Several studies have consistently revealed that language anxiety can impede foreign/second language production for instance English performance (Akkakoson, 2016; Zhang, 2014), but some studies have proved that there were no relationship and correlation (Debreli and Demirkan, 2016). The objectives of this study are to identify the washback effect of SBOE performance from the teachers' perception, and to investigate the causal relationship of school-based oral performance with fear of negative evaluation. The research hypothesis is that $\mathrm{H}_{\mathrm{o} 2}$ : There is no significant causal relationship between the students who have passed the SBOE with fear of negative evaluation.

\section{Literature Review}

\subsection{Washback Effect}

Washback effect refers to the effects of assessment practices on students, teachers, and administrators, and indirectly on schools and communities (Toksoz and Kilickaya, 2017). There are positive and negative washback effects. Positive washback effect refers to tests and examinations that influence teaching and learning positively (Alderson \& Wall, 1993, pp. 15). Negative washback is the negative influence of tests on teaching and learning. Alderson and Wall (1993) pointed out that a negative washback is defined as the undesirable effects on teaching and learning of a particular test. The test may fail to reflect the course objectives to which they are supposedly related. 
Toksoz and Kilickaya (2017) conducted on washback effects in Language Teaching in Turkey between 2010 and 2017. Their studies reviewed the washback effects studies conducted on high-stakes examinations in Turkey. According to Hatipoglu (2016) the education system in Turkey is very exam oriented. Yıldırım (2010) investigated students' and teachers' teaching and learning practices in the preparation process for ECFLUEE (English Component of the Foreign Language University Entrance Exam) in Turkey and he found that the students had difficulty in speaking and writing in English. Therefore, it was indicated a negative washback effect of ECFUEE.

Attab, Qureshi and William (2014) had investigated the washback effect of the Pakistani Intermediate English examination. The results revealed that students were scoring high in the intermediate examinations. It was also revealed that teachers' practices were influenced by examination content and format which also affects students' learning. The washback on learning is strong since students also demand practice of examination related activities and rely on the material, find guides from the English teachers.

\subsection{Causal Relationship}

This study defines the causal relationship as the change in one event (dependent variable) is the result of the occurrence of the other event (independent variable). In other words, the change in the independent variable causes changes in causation relationship between school-based oral performance with fear of negative evaluation as dependent variable. Perhaps, it is a cause and effect relationship between schoolbased oral performance (independent variable) with fear of negative evaluation (dependent variable). It is said as causal relationship when the mean value of the dependent variable increases or decreases, as it is resulted of the independent variable. Therefore, in this study the mean level of fear of negative evaluation is resulted from the causation indicated from the school-based oral performance of the students in the mid-term English examination 2017.

In conclusion, the causation indicates that the mean level of fear of negative evaluation is affected by the school-based oral performance because of the high or low SBOE results in the mid-term English examinations 2017. The strength of the causal relationship is determined by the effect size in the analysis.

\subsection{Previous Studies}

Gopang, et. al. (2017) investigated foreign language anxiety at tertiary level in Pakistan. They found that students experienced high level of language anxiety. In focused interview the students recorded that poor academic background was one of the reasons why students experienced fear of negative evaluation in language anxiety. The study suggested a few learning and teaching strategies, for example teachers should create rapport with students especially with those who are inactive and passive 
in learning English. This is what the English teachers have done in the government secondary schools in Putrajaya Federal Territory. They have a close teacher-student relationship in order to minimize the anxiety level of students in the classroom. Teachers should respect students' feeling and emotions in front of the peers in the classroom.

Their study also revealed that fear of negative evaluation was the lowest language anxiety compared to communication apprehension and test anxiety. The study is not in line with this study because in this study fear of negative evaluation is the highest language anxiety compares to communication apprehension and test anxiety.

A study made by Tzoannopoulou (2016) at Greek University, revealed that there was a negative correlation between fear of negative evaluation and language performance. Fear of negative evaluation was the main cause of language anxiety. Sources of fear of negative evaluation are including negative judgment by others, disapproval by others, making mistakes and leaving unfavourable impression on others. His study is in line with this study as fear of negative evaluation is the highest anxiety and there is a negative correlation between fear of negative evaluation and language performance.

Shafiq, Irma, Ahmad Hifzurrahman, Wan NorHaizar (2016) revealed that the diploma students at University Malaysia Perlis who studied English as a L2 experienced the highest level of fear of negative evaluation. However, the relationship between fear of negative evaluation and language achievement was a positive relationship, meaning that the higher they achieved in the language achievement test, the higher the fear of negative evaluation.

Zia and Norrihan (2015) revealed that fear of negative evaluation had scored the highest level compared to communication apprehension and test anxiety among the first year undergraduate students from Nangarhar University, Afghanistan. Amiri and Ghonssoly (2015) also found that students had scored the highest level in fear of negative. Results showed that it affected the students' English test achievement among medical students at Gonabad University of Medical Sciences, Iran.

Marfuzah, et. al. (2013) found that L2 students at Universiti Teknologi MARA (UiTM) Perak experienced high mean level of fear of negative evaluation. Classroom activities might develop a sense of competitiveness among each other.

Shabani (2012) found that the level of fear of negative evaluation was high and he considered it as a serious source of language anxiety. The students feared of failing in the classroom, feared of forgetting vocabularies and unprepared of teachers' questions. The main sources of provoking fear of negative evaluation were fear of saying wrong things, fear of doing wrong things, unfavourable impressions on others and negative judgment by others.

Tzoannopoulou (2016) and Mathieson (2016) agreed that there was a negative relationship between fear of negative evaluation and language performance but Shafiq 
Hizwari, Irma Ahmad, Ahmad Hifzurrahman, Wan NorHaizar (2016) pointed out that there was a positive relationship between fear of negative evaluation on language performance. There is both agreement and disagreement, but what links the two arguments is the fact that both results are contradictory.

\section{Research Method}

\subsection{Research Design}

Table 1: Approach and Type of Mixed Methods

\begin{tabular}{ll}
\hline Approach & Type \\
\hline QUAN qual & sequential $\longrightarrow$ \\
\hline
\end{tabular}

Source: Morse's (1991) Notation System

Table 1 illustrates a mix-method approach of this study. It is called an explanatory sequential mixed method design in which quantitative and qualitative data were collected in sequential, analyzed separately, and then explained. Data were collected in two phases. The researcher collected the quantitative data and secondary data from the students through the English teachers during the first phase. The semi-structured interviews were conducted with the English teachers during the second phase after the first phase data were analysed and interpreted.

\subsection{Analysis Method}

For the objective number one, the interviews were recorded by video recording. Data were analysed by using content analysis according to the theme and codes. For objective number two data were collected through FLCAS (Horwitz, Horwitz and Cope, 1991) and analysed by descriptive analysis.

\subsection{Population}

The population is the form four students who have passed the SBOE and English teachers from 11 government secondary schools in Putrajaya Federal Territory.

\subsection{Sample Size}

The sample size is $30 \%$ of the number of students who have passed the SBOE in the mid-term examination 2017. For the qualitative method, this study has selected randomly four English teachers from 11 government secondary schools. 


\subsection{Research Instrument}

For quantitative method, the replicated, adapted and translated questionnaire (FLCAS) by Horwitz, Horwitz and Cope $(1986,1991)$ is the instrument to measure the fear of negative evaluation and the mid-term examination's results served as a secondary data. FLCAS consists of 33 items in a 5-point likert scale that range from "strongly agree" to "strongly disagree". The instrument consists of Part A and B. Part A is designed to obtain respondents' demographic information including age, gender, race and SBOE results. As for section B, 33 items are replicated and adapted from Horwitz, Horwitz and Cope's (1991) FLCAS questionnaire. The independent variable in this study is the students who have passed in SBOE. Results of SBOE were collected from the English teachers. The dependent variable in this study is fear of negative evaluation (FNE). It measures item number 2, 7, 13, 19, 23, 31 and 33. Descriptive analysis was used to analyze the quantitative data. For qualitative method, semi-structured interviews were held with the four English Teachers. Content analysis was used to analyze the qualitative data according to the theme and codes related to fear of negative evaluation.

\section{Results and Discussion}

The mid-term examination 2017 revealed that the students' results in SBOE were high. 74 students had scored "excellence"; 171 students had scored "good"; 56 students had scored "satisfactory" and only one student had scored "weak". Findings from the quantitative method showed that the mean level of fear of negative evaluation for male students is 1.81 and female students is 1.80. The mean level of fear of negative evaluation is low (Low: From 1.00 to 2.33). High results in SBOE had affected the mean level of fear of negative evaluation. The effect size of oral performance on fear of negative evaluation is large because the partial eta squared shows the value of 0.106 . According to Whitehead, Julious, Cooper and Campbell (2015) the general rules of thumb on magnitudes of effect sizes used in statistical analyses recorded that the large effect size in Partial Eta is the value of 0.14 (in one-way MANOVA).

This study has successfully rejected the null hypothesis. The result of partial etasquared is used to form a decision. The partial eta-squared is 0.106 and the effect size is considered large. The results are said to be statistically significant and support is inferred for the relationship (Gigerenzer et al., 1995) between the form four students who have passed the SBOE with fear of negative evaluation. Therefore, there is a significant causal relationship between the students who have passed the SBOE with fear of negative evaluation. The high performance of students in SBOE have caused low mean level of fear of negative evaluation. In other words, there is negative relationship the students who have passed the SBOE with fear of negative evaluation.

Data from the semi-structured interview were analysed by content analysis. The approach used was a conventional content analysis which coding categories were 
derived directly from the text data (Hsiu and Shannon, 2005).

The data were encoded to organize text-based segments before the presentation of the intent of the data (Rossman and Rallis, 1998, p. 171). Codes were made based on the theme of this study. Gibbs (2009) mentioned it as human activity in a certain atmosphere. Once the data was encoded, the next step was to make the details into the codes. This study created codes both on pre-set and open. The pre-set codes derived from the theory. As part of the coding process, it is important to jot down notes of the ideas that emerged. The notes may suggest new interpretations as well as connections with the quantitative and secondary data. The notes usually point toward questions and issues that the study is looking for.

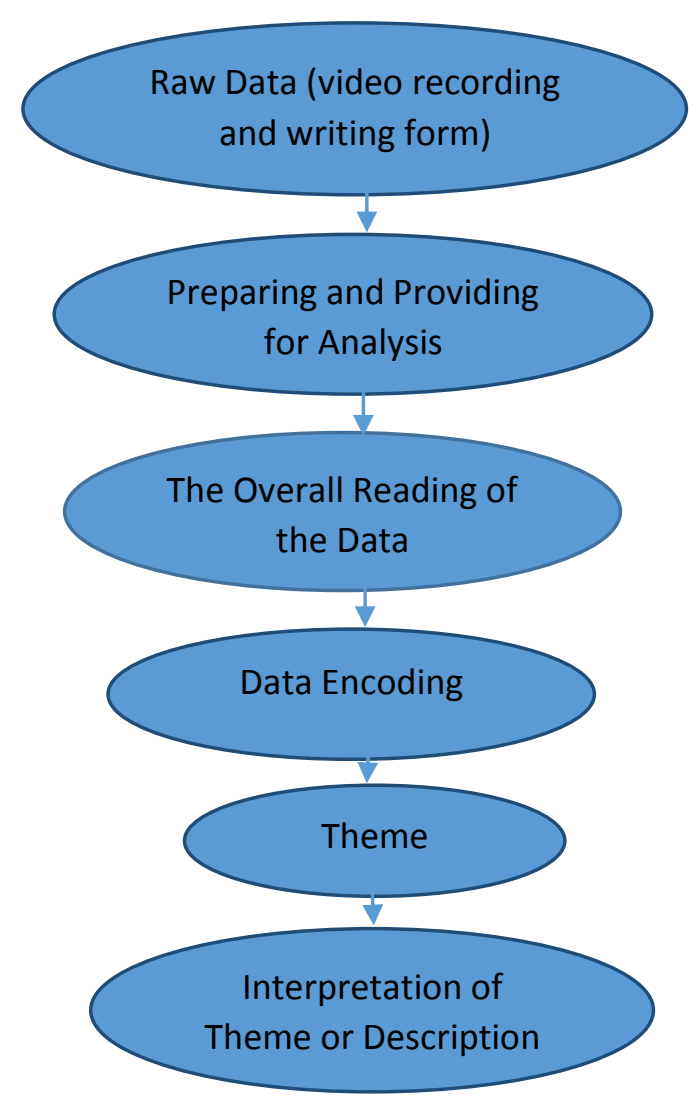

Figure 1: Data Preparation Steps

Figure 1 illustrates the qualitative method data preparations steps. After interpreting the data, findings revealed that there is a positive washback of SBOE in the mid-term English examination 2017. The following factors contributed towards the positive influence of SBOE on students' result. From the semi-structured interviews, the English teachers reported that SBOE has given good impact on the students. There are as follows:

a) Students build their self-confidence.

Students are not fear of being evaluated because SBOE is very helpful and effective in improving students' speaking and listening skill. The students are confident to communicate in the English language because the teachers create the English class interesting by doing group work presentation, choral speaking, 
public speaking and drama.

b) The average and weak students memorize the scripts.

The teachers and the good students help the average and weak students to memorize the scripts. They practice together in pair and group works.

c) Oral language is good for self-esteem.

The students share their daily routine, interests, favourite games and problems in their studies. SBOE gives good opportunities to students in order to improve their vocabularies, sentence constructions, grammar and other skills such as speaking, reading and listening.

d) Boost self-confidence in oral language

SBOE can boost students' confidence level in oral language. The students practise together and it can boost the self-confidence in weak students. The teachers give motivation to students when they never say wrong if the students have made mistakes. They keep asking the students to keep on trying.

Qualitative results revealed that all the teachers have agreed that students are confident, not worried, not nervous, not self-conscious, not panic, not upset and not forgetful during the SBOE. Teachers have created positive and conducive classroom environments because the exposure to use the English language in the classroom is very important. Students are free to express their views and feelings without having the fear of making mistakes. As a result, they are comfortable to use and converse in English effectively. Students do a lot of activities in the English class interaction such as presentations, pair works, group works and the activities are fun activities. Therefore, they feel at ease and confident. They are focused because the activities are very specific. They also do brain storming in groups, discussing all the points and finally do the script. Teachers and students have close relationships so students are free to share their views and come out with brilliant ideas. Students are very active to ask and answer the questions during the English class interaction. The English teachers give them the opportunity and chances to try. They never say wrong when students' answers are incorrect. They ask the students to keep-on trying. When the teachers never say wrong, the students are not scared to answer the questions. They give more speaking activities in the classroom such as seminars, dialogues, questionnaires and radio calls at the station.

Majority of the students can answer the questions when they are asked during the SBOE. Students react positively during the SBOE. They understand the abstract, the passages and questions that have given to them. The teachers conclude that they are positive while communicating with the teachers and among themselves. They practise among themselves and because of the preparation that they have made, they perform well in the SBOE.

For a complete explanation of the output, this study has interpreted the main required assumptions (Pallant, 2013) for the objective number two. There are assessment of outliers, normality test, mean value and effect size. 


\section{1) Outliers}

An outlier is a data point which does not appear to come from the same distribution as the rest of the data. This may occur, for example, if a participant is not following or has misunderstood the given instructions. In this study there is no incorrect data entry and no missing value are found.

2) Normal Distribution

According to Awang (2015), Mohamad et. al. (2016), data are considered normally distributed if the absolute value of its skewness fall within the range of -1.5 to 1.5. In this study, the skewness falls within the range of -1.5 to 1.Table 3 shows the assessment of normality for fear of negative evaluation in FLCAS (Horwitz, Horwitz and Cope, 1991).

Table 2: The Assessment of Normality for All Items

\begin{tabular}{ll}
\hline \multicolumn{2}{c}{ Skewness } \\
\hline Item & FNE2 \\
\hline FNE7 & .679 \\
FNE13 & .935 \\
FNE19 & .683 \\
FNE23 & .734 \\
FNE31 & .955 \\
FNE33 & .720 \\
& .598 \\
\hline
\end{tabular}

3) Mean Value

The mean value of fear of negative evaluations are shown in Table 3. The male students obtained the mean value of 1.81 and the female students obtained the mean value of 1.80 .

Table 3: Mean Value of Fear of Negative Evaluation

Gender Fear of Negative Evaluation

$\begin{array}{ll}\text { Male } & 1.81 \\ \text { Female } & 1.80\end{array}$

This study concluded that high SBOE result affected the mean level of fear of negative evaluation. The decision is made based on the partial eta-squared because the partial eta-squared showed the value of the effect size (Pallant, 2013).

4) Effect Size

In this study, it is necessary to include the strength of relationship of the effect size in 
order to truly understand the importance of the findings. According to American Psychological Association (2001), the effect size is the strength of the relationship is for the reader to fully understand the importance of the findings. The general rules of thumb on magnitudes of effect sizes used in statistical analyses (for one-way MANOVA) recorded that the large effect size in the partial eta-squared is the value of 0.14 (Whitehead, Julious, Cooper and Campbell, 2015). In this study, the partial eta-squared is 0.106 . The effect size or the strength of the cause and effect relationship between the students who have passed in the SBOE with fear of negative evaluation is large.

The causal relationship between school-based oral performance with fear of negative evaluation is said to be statistically significant. The students with high performance in SBOE had caused low mean level of fear of negative evaluation. In other words, there is a negative relationship between the students who had passed the SBOE with fear of negative evaluation.

\section{Conclusion}

This study used both quantitative and qualitative methods employing multiple sources of data collection. The data collection primarily used a questionnaire survey from FLCAS (Horwitz, Horwitz and Cope, 1991) and semi-structured interviews. Data were collected from students and English teachers from the Putrajaya Federal Territory government secondary schools which have produced the highest number of students passed in the English subject in SPM for ten years in a row (Malaysia, Ministry of Education 2017). The quantitative method focused on the cause and effect relationship between school-based oral performance of the students in the mid-term English examination 2017 with fear of negative evaluation. The qualitative method focused on teachers' perception of the washback effect of SBOE. The qualitative evidences helped to support the quantitative evidences. In addition, secondary data collection proven as evidences supporting the findings. The mixed-method in this study is called an explanatory sequential mixed-method design in which quantitative and qualitative data were collected in sequential, analysed separately, and then explained. Based on the findings students had scored high results in the SBOE. $81.1 \%$ of them had scored "excellent" and "good" in the SBOE.

This study produced results which corroborate the findings of a great deal of the previous works in this field, even though some of the previous results were inconsistent with this study but these findings supported previous theories. Finding from this study had proved that high performance in the SBOE affected fear of negative evaluation. Oral language plays an important role in acquiring and learning the language. The study also clearly demonstrated that oral performance had a major impact on fear of negative evaluation for English language learners. Research literatures on performance for English learners offered evident that students with moderate to high level of language anxiety produced low performance in English language. This study has proved that students with high performance in the oral language are not affected by the fear of negative evaluation but high oral performance 
has affected the communication apprehension. Based on the SBOE results and teachers' perception on the washback effect of SBOE, this study offers evidence on the effectiveness of the SBOE.

One of the goals of the SBOE is to judge the level of competency students achieve in speaking. Therefore, oral assessment can also produce useful information for diagnostic purposes to assess what students know and they can help teachers to determine groups of students need special attention. SBOE tasks are also instructional because it depends on the models, allowing students to actively engage in worth-while learning activities within the classroom. In the SBOE settings, students may be encouraged to seek out additional information, work in teams and try various approaches. From the researcher's point of view, the SBOE strategies are all beneficial for the form four students as the students benefit from the engagement in classroom activities. Furthermore, the SBOE is a situation where students are asked to actively communicate in L2. In the teachers' report, it explained how SBOE can help to lower down the fear of negative evaluation. Additionally, the mid-term results had proved that students with high result in the SBOE experienced low mean level of fear of negative evaluation.

Finding in this study supports the previous studies by Tzoannopoulou (2016) and Mathieson (2016) when there is a cause and effect on negative relationship between fear of negative evaluation and English performance. This finding is in agreement with Gopang, et. al. (2017), Zia and Norrihan (2015), Amiri and Ghonssoly (2015), Marfuzah, et. al. (2013) and Shaabani (2012) when the results proven that fear of negative evaluation is the highest anxiety compared to communication apprehension and test anxiety.

Based on the teachers' reports, this study can conclude that the SBOE is very examoriented. The results are clearly indicated that the teachers are teaching towards the examinations, for instance the SBOE appears to be directly influenced by the four models set by the Examination Syndicate and it follows the assessment procedures. Students normally just concentrate on scoring in their examinations and schools spend too long preparing students to pass the examinations. Family and friends often compare students' performance to see who has the most A's in order to determine who has done well. The school curriculum for English language calls for a radical change because language is a skill and is not predominantly academic and theory. Furthermore, the SBOE with the four models have been used for nearly 20 years.

However, the English teachers in the government secondary schools in Putrajaya Federal Territory, have created a conducive classroom environment for the students. The teachers reported that the students have the freedom to give their ideas, the teachers never say wrong if they make mistakes and they do the English activities in team work. In addition, the students do fun activities in the English class interactions. Therefore, the English class activities are more relaxed and casual. The students do not feel fear of being negatively evaluated for the tests and preparing for the examinations. 
As a result, they obtained high performance in the SBOE and experienced low mean level of fear of negative evaluation.

\subsection{Contributions to the Body of Knowledge}

Generally, this study suggests two broad tasks for future work. The first involves the development of national curriculum in English language where dependence upon oral English language. This type of English curriculum is essential in order to decrease fear of negative evaluation. However, the viability of communicative approach through oral English language is limited in the classroom but the development of new curriculum could support the use of English language in the school activities and cocurriculum. Currently, the oral language comprises 30\% component in the English subject. This study suggests oral language should be higher than $30 \%$ as a component in the English subject.

The second task for work focuses on the development of English language training and skill for the English teachers. Oral language as a key part in English language activities should be included in the development of new English curriculum and teachers should be given training on the new communicative approach through oral language.

In addition to these two broad areas, based on the research objectives, results and findings, this study suggests a variety of key points of leverage for English activities to assist in developing effective communication skills to avoid fear of negative evaluation. These points of leverage are listed in a particular sequence for specific reasons. The points of leverage involve a combination of the followings:

\section{i. New Approaches}

Efforts to rethink and implement new approaches effective responses to emerging communication because $80 \%$ of the students have passed in English subject but they still could not communicate well (Malaysia, Ministry of Education, 2017). Therefore, new approaches in English language are necessary to increase the performance of English language among the Malaysian students in order to lower down the fear of negative evaluation because other studies made in the Malaysian schools showed that students experienced moderate to high level of language anxiety.

\section{ii. New English Curriculum}

Initiatives to build a new curriculum in English language. The English curriculum has to be reviewed and renewed. Focus should be given to develop on oral English language and efforts to communicate in English in the school at all times. The potential new English curriculum activities need to be further discussed by the Ministry of Education Malaysia and the English teachers. It is suggested that a higher order thinking skill should be introduced in oral-based English curriculum. 


\subsection{Future Research}

For future research, this study suggests to investigate how to develop a new oral-based English curriculum for the schools.

\section{Acknowledgements}

Special appreciation to the Examinations Syndicate, Education Planning and Research Division, Ministry of Education Malaysia and all the government secondary schools in Putrajaya Federal Territory for their kind co-operations. This study would not have been possible without their co-operations.

\section{References}

Aftab, A., Qurashi, S. and William, I. (2014). Investigating the washback effect of the Pakistani Intermediate English Examination. International Journal of English and Literature, 5(7), 149-154.

Akkakoson, S. (2016). Speaking Anxiety in English Conversation Classrooms among Thai Students. Malaysian Journal of Learning and Instruction, 13, 63-82.

Alderson, J. C., \& Wall, D. (1993). Does Washback Exist? Applied Linguistics, 14(2), 115129.

American Psychological Association. (2001). Publication Manual of the American Psychological Association (5th ed.). Washington, DC: Author.

Amiri, M. \& Ghonsooly, B. (2015). The Relationship between English Learning Anxiety and the Students' Achievement on Examination. Language Teaching and Research, 6(4), 855-865.

Awang, Z. (2015). SEM Made Simple. Bandar Baru Bangi: MPWS Rich Publication.

Debreli, E. \& Demirkan, S. (2016). Sources and Levels of Foreign Language Speaking Anxiety of English as a Foreign Language University Students with regard to Language Proficience and Gender. International Journal of English Language Education, 4(1), 49-62.

Gibbs, G. (2009). Analysing Qualitative Data. Forum Qualitative Sozialforshung/Forum: Qualitative Social Research. Retrieved September, 202017 from http://nbnresolving.de/urn:nbn:de:0114-fqs100341.

Gigerenzer, G., Swijtink, Z., Porter, T., Daston, L., Beatty, J., \& Kruger, L. (1995). The empire of chance: How probability changed science and everyday life. Cambridge, UK: Cambridge University Press.

Gopang, I. B., Ansari, S., Ume, K. \& Loghari, A. (2017). An Emperical Investigation of Foreign Language Anxiety in Pakistani University. International of English Linguistics, 7(2), 21-31.

Hatipoğlu, Ç. 2016. The impact of the university entrance exam on EFL education in Turkey: Pre-service English language teachers' perspective. Procedia-Social and Behavioral Sciences, 232, 136-144.

Horwitz, E. K., Horwitz, M. B. \& Cope, J. A. (1991). Foreign Language Classroom Anxiety. In In E. K. Horwitz \& D. J. Young. Language Anxiety: From Theory 
andResearch to Classroom Implications (pp. 27-39). Eaglewood Cliffs, New Jersey: Prentice Hall.

Horwitz, E. K., Horwitz, M. B. \& Cope, J. A. (1986). Foreign Language Classroom Anxiety. Modern Language Journal, 70, 125-132.

Hsiu. F. H. and Shannon, S. E. (2005). Three Approaches to Qualitative Content Analysis. Qualitative Health Research. 15(9), 1277-1289.

Krashen, S. (1982). Principles and Practice in Second Language Acquisitiion. Oxford: Pergamon.

Liu, M. \& Huang, W. (2011). An Exploration of Foreign Language Anxiety and English Motivation. Retrieved November 6, 2016 from http://dx.doi.org/10.1155/2011/493167.

Malaysia, Ministry of Education (2017).

Marfuzah, R. et. al. (2014). Gender and Language: Communication Apprehension in Second Language Learning. Procedia-Social and Behavioral Sciences, 123, 9096.

Mohamad, et. al. (2016). Measuring Positive Youth Development: The Confirmatory Factor Analysis (CFA). Retrieved December 20, 2016 from http://hrmars.com/hrmars_papers/Parental_and_Peer_Attachment_and_its_ Relationship_with_P.

Mahfuzah, R. et. al. (2015,). Language and Gender: Fear of Negative Evaluation in Second Language Learning. Paper presented at the Proceeding of the 3rd Global Summit on Education GSE 2015, Kuala Lumpur, Malaysia.

Malaysia, Ministry of Education (2017).

Morse, J. M. (1991). Approaches to qualitative - quantitative methodological Triangulation. Nursing Research, 40, 120-123.

Pallant, J. (2013). SPSS survival manual: A step by step guide to data analysis using IBM SPSS (5th ed.). Open University Press: McGraw - Hill Education.

Rossman, G. B. \& Rallis, S. F. (1998). Learning in the field: An introduction to qualitative research. Thousand Oaks, CA: Sage Publications.

Shabani, M. B. (2012). Levels and Sources of Language Anxiety and Fear of Negative Evaluation among ELF Learners. Retrieved from http://www.academypublication.com/issues/past/tpls/vol02/11/21.pdf.

Shafiq, H., Irma, A., Ahmad, H. \& Wan NorHaizar. (2016). Second Language Anxiety among Diploma Students in Technical University, Retrieved from http://www.dspace,unimap.edu.my.

Toksoz, I. \& Kilickaya, F. (2012). Review of Journal Articles on Washback in Language Testing in Turkey (2010-2017). Lublin Studies in Modern Languages and Literature, 41(2), 184-204.

Tzoannopoulou, M. (2013). Foreign language anxiety and fear of negative evaluation in the Greek university classroom. Paper presented at the 21st International Symposium on the Theoretical and Applied Linguistic (ISTAL 21), Thessaloniki, Greece. April 2013.

Whitehead, A. L., Julious, S. A., Cooper, C. L. \& Campbell, M. J. (2015). Estimating the sample size for a pilot randomised trial to minimise the overall trial sample 
size for the external pilot and main trial for a continuous outcome variable. State Methods Med Res, 25 (3), 1057-1073. doi: 10.1177/0962280215588241.

Yıldırım, Ö. (2010). Washback effects of a high-stakes university entrance exam: Effects of the English section of the university entrance exam on future language teachers in Turkey. The Asian EFL Journal Quarterly, 12(2), 92-116.

Zhang, R. (2014). Exploring the Relationship between Chinese First Year University Students' Beliefs about Language Learning and Foreign Language Anxiety. International Journals of Applied Linguistics \& English Literature, 3(1), 28-44.

Zia, Z. \& Norrihan, S. (2015). EFL Learners' Levels of Classroom Speaking Activities in Afghanistan. International Journal of English and Education, 4(1), 239-249. 